\title{
Рецензии
}

\author{
УДК $82-21$
}

\section{Е.А. Подшивалова}

О «ЛЕВОЙ РУКЕ ПИАНИСТА» (Рещензия на кн.: Когут К.С., Хрящева Н.П. Поэтика драматургии А.П. Платонова конца 1930-х - начала 1950-х гг.: межтекстовый диалог. СПб.: Нестор-История, 2018. - 280 с.)

DOI: 10.35634/2412-9534-2019-29-6-1088-1090

Драматургия до сих пор остается менее изученной частью творческого наследия Андрея Платонова. На необходимость ее полного издания и тщательного исследования обращала внимание Н.А. Корниенко еще десятилетие назад. Однако целостное осмысление поэтики платоновских пьес можно считать только начатым. Поэтому выход в свет рецензируемой монографии представляется важным и своевременным.

Прежде всего отметим, что К.С. Когут и Н.П. Хрящева рассмотрели позднюю драматургию А.П. Платонова в хронологической последовательности, что позволило им впервые целостно ее описать. При этом ученые избежали узко направленного взгляда, соотнесли драматургические произведения с прозой, публицистикой, письмами, записными книжками писателя. Таким образом целостность драматургического мышления А. Платонова оказалась вписанной в целостность его разнородового и многожанрового наследия.

Начиная свое исследование, авторы монографии обосновывают подходы к материалу и останавливают свой выбор на тех, которые позволяют результативно прочитывать произведения А. Платонова, более точно толковать его образы и авторскую концепцию мира и человека, соотнося их с жизненным материалом (фактами биографии и социально-исторической действительностью). Ученые показывают, что наиболее продуктивными в современном платоноведении являются контекстуальный, мотивный, микроисторический, микропоэтический, генетический методы исследования. Их применение позволяет выявить метатекстуальную природу драматургии и - шире - творчества А. Платонова. Поэтому в конечном итоге все используемые подходы варьируют контекстуальный или восходят к нему. Толкование рассмотренных в монографии пьес сделано на основании соотнесения их с разными контекстами - от контекста жизни и творчества А. Платонова до контекста древнерусской литературной и устно-поэтической традиции.

Каждая анализируемая в монографии пьеса включена в свои контекстуальные связи.

Драма «Голос отца» рассматривается на фоне элегической, библейской древнерусской, пушкинской традиций, в соотнесенности с философскими идеями Н. Федорова, ранними утопическими произведениями А. Платонова, романом «Чевенгур», повестью «Котлован», публицистическими статьями писателя и его письмами. Элегический контекст устанавливается через тематику и мотивику: сопоставляются образные ряды ремарок в «Голосе отца» и элегий В. Жуковского и поздних стихотворений А.С. Пушкина, в частности «Вновь я посетил...». Библейский контекст пьесы описывается через сопоставление выраженных в ней идей и мотивов с религиозными идеями и мотивами, содержащимися в литературном творчестве святителя Игнатия Брянчанинова. Авторы монографии считают взаимосвязанными библейский и элегический контексты произведения А. Платонова: они показывают, как элегический контекст на уровне микропоэтики и через аллюзорные отсылки нагружается библейскими смыслами и транслирует тему родовой памяти и духовной вертикали, мыслимой автором сокровенной составляющей человеческой жизни. Эту же тему поддерживает контекст древнерусской литературы («Житие Феодосия Печерского»). Связь «Голоса отца» с этим произведением описана через образ беса и его сюжетные функции, а также через семантику смеха, разработанную в древнерусской традиции. Мотив бесовства подключает к пьесе автокантексты А. Платонова, в частности, ранние утопические произведения, произведения конца 1920-х - начала 1930-х гг., рассказ «Счастливый корнеплод» (1943 г.). Автоконтексты поддерживают авторскую идею пьесы о взаимосвязи поколений через установление родовой памяти и духовного всеединства. 
В первой главе книги показано, что литературный контекст выводит А. Платонова на полемическую позицию по отношению к социально-политической жизни. 1930-х гг., на тему разрыва духовной и родовой связи поколений в результате идеологизации человека. На этом основании сделан важный вывод о разнонаправленности контекстуальных парадигм рассмотренного произведения. По мысли исследователей контекстовые связи формируют глубинные художественные смыслы пьесы «Голос отца» и позволяют писателю говорить с читателем на языке эстетики, а не политических штампов.

Во второй главе анализируется поэтика пьесы «Волшебное существо» в соотнесенности с пьесой «Без вести пропавший, или Избушка возле фронта» и рассказами «Афродита» и «Возвращение». Через эти произведения А. Платонов проводит тему возвращения человека от войны к мирной жизни, тему разделившего людей опыта жизни на фронте и в тылу, тему выстраивания прерванных исторической драмой межличностных и семейных связей. Исследователи справедливо считают, что наиболее важным для данных произведений является биографический контекст, извлеченный ими из изданных писем А. Платонова и комментариев к ним. Они представили эти две пьесы и рассказы как художественную систему, разрабатывающую тему возвращения, где «Без вести пропавший, или Избушка возле фронта» является претекстом «Волшебного существа», а «Волшебное существо» - претекстом «Возвращения». Динамика данной контекстовой связи прослежена через образы героинь, воплощающих семантику телесности и одухотворенности, проявленную через мотив еды. Мотив еды рассматривается как «питание тела» и «питание души». Через семантику еды как «питания души» Платонов возвращается к заданному в «Голосе отца» мотиву памяти и ее воскрешающей функции. Авторы монографии показывают, что в «Волшебном существе» мотив воскрешения воплощается через образно-стилевой и жанровый уровни произведения, смоделированные по законам волшебной сказки. Завершается анализ пьесы описанием семантики библейских мотивов, проекцией образа главной героини - Марии - на сюжет апокрифа «Хождение Богородицы по мукам», а главное - на выраженное в нем желание Богородицы мучиться вместе с христианами, которое воплощает персонаж пьесы. От этого сюжета тянутся смысловые нити к нравственному воскрешению Иванова, героя рассказа «Возвращение».

К.С. Когут и Н.П. Хрящева обнаружили в пьесе «Волшебное существо» важный смыслообразующий пласт, создаваемый пушкинским биографическим и творческим контекстом, выводящим А. Платонова к трагедийному опыту современности.

Пушкин является героем следующей пьесы писателя - «Ученик Лицея». И она, как и предшествующие, проецируется на биографический контекст ее автора. Исследователи считают, что А. Платонов написал «вещь» о сыне, исполнив тем самым свое потаенное желание, долго преследовавшее его после тяжелой потери. Называя метод своего анализа уликовым, авторы монографии прочитывают образ Пушкина в пьесе одновременно как юный и старый. Эта двойственность оборачивается полисемичностью: герой воплощается одновременно в сыновней и отеческой ролях. И эти две роли проецируются на биографический сюжет потери сына, переживаемый А. Платоновым. Показав, что в образе юного старика Пушкина писатель смоделировал свою биографию и биографию своего поколения, исследователи обратились к литературному контексту, в котором разработана тема безвинной жертвы («казни сыновей в эпоху сталинского террора»). Прослежены параллели между «Учеником Лицея» и «Реквиемом» А. Ахматовой и поэмой А. Твардовского «По праву памяти».

Далее авторское мироотношение раскрывается в пьесе через образ лицейского братства и транслирующие его мотивы - «охранительный» мотив и мотив еды в их воссоединительной и одухотворяющей функции; мотив смерти и мотив еды в их разрушительной и отелеснивающей человека функции; мотив юродства, воплощающий образ Музы поэта. Последний мотив ориентирует «Ученика Лицея» на традиции народной сказки и древнерусской литературы. Жанр волшебной сказки, по мнению авторов монографии, и в «Волшебном существе», и в «Ученике Лицея» позволяет А. Платонову воплотить идею сказочного преображения мира. В первой пьесе преображение осуществляется через образ платья, во второй - через Слово.

Последняя незаконченная пьеса А. Платоноваа «Ноев ковчег» рассматривается как итог выраженной в творчестве писателя философии жизни. К.С. Когут и Н.П. Хрящева начинают ее анализ с описания мотива чужеземства, появившегося еще в пьесах 1930-х годов - «Шарманка» и «14 Красных избушек». Данный мотив формирует тему подмен, тему профанного объединения человечества. Соотнося три пьесы, ученые показывают жанровую динамику и соответственно динамику авторской оценки 
исторического процесса 1930-х - 1940-х годов: «Шарманка» характеризуется как социальная сатира, «14 Красных избушек» - как трагедия, написанная языком абсурда, «Ноев ковчег» - как мистерия-фарс. Художественно осмысляя легенду о всемирном потопе в «Ноевом ковчеге» и соотнося ее с судьбой человеческой цивилизации, А. Платонов показывает тупиковый путь. Сопоставляя мистерию-фарс А. Платонова с рассказом Л. Леонова «Уход Хама», авторы монографии показали, что при всем различии эти произведения сближены общим эсхатологическим предчувствием их авторов - предчувствием людей, переживших личные и социально-исторические катастрофы первой половины XX в.

Н.А. Корниенко обратила внимание на то, что Андрея Платонова нужно читать сердцем. При всей оснащенности монографии К.С. Когута и Н.П. Хрящевой научным инструментарием она не является только хорошо выполненным профессиональным трудом. За всеми контекстами, в которые исследователи вписали изученные произведения, ощущается стремление глубже понять не только Платонова-художника с его «не общедоступным» языком, но и человека, чей жизненный и духовный опыт мог получить выражение именно в таком языке. Книга К.С. Когута и Н.П. Хрящевой - это событие с писателем.

Поступила в редакцию 15.12.2019

Подшивалова Елена Алексеевна, доктор филологических наук, профессор ФГБОУ ВО «Удмуртский государственный университет» 426034, Россия, г. Ижевск, ул. Университетская, 1 (корп. 2) E-mail: podshlena1@mail.ru
Podshivalova E.A.,

Doctor of Philology, Professor

Udmurt State University

Universitetskaya st., 1/2, Izhevsk, Russia, 426034

E-mail: podshlena1@mail.ru 